\title{
A Research on Internet-of-Things-Based Business Model of China Mobile
}

\author{
Shi Xin \\ International trade Department \\ Shengyang Aerospace University \\ Shengyang China
}

\begin{abstract}
The rise and development of Internet of Things has a Profound impact on the enterprise which changes the way of enterprises' business scope, operation mode. With the growing maturity of technology and standards related to Internet of Things, man - machine communication and machine to machine communication based on M2M is the secondary important blue ocean after human communication. As the leading operator in the telecom industry, China Mobile faces serious challenges in the time of Internet of Things and competitive pressures, and also embraces the opportunity to strengthen its competitiveness.This thesis based on the analysis of the concept development history and operational features of Internet of Things, discuses the application fields and operational features combining the definitions elements and characteristics of Business Model and proposes the applicability of various business models suitable for the development of Internet of Things. This dissertation analyses the theoretical study and practical business models, combined with the actual development situation of Internet of things of China's mobile, proposes that the development of China Mobile IOT should be divided into two kinds of markets: the personal and family market and the industry market. In the personal and family market, China Mobile should abide by the model of "unified platform as the basis, comprehensive operation as the motivation", and in the industry market, it should conform to the operational model of "Professional Changes as keys ,Personalize doperation as breakthrough throughs",finally, in the further development, providing the strategic recommendations to help China Mobile to achieve a strategic transformation, there are four steps to carry out: firstly, it is necessary to speed up the construction of high-quality intelligent network, secondly, it is fundamental to establish network access and management platform, thirdly, it is important to jointly build a mobile alliance of Internet of Things, fourthly it is vital to launch the marketing activities on Internet of Things.
\end{abstract}

Keywords-Internet of Things; Business Model; China Mobile; Applied Research

\section{INTRODUCTION}

The concept of Internet of Things was proposed by EPCGlobal Company and MITAutoroLab (Massachusetts Institute of Technology automatic identification laboratory) in the end of 20th century. The rise and development of Internet of Things has a profound impact on the enterprise, which changes the way of the enterprises' operation and results in some new concepts and theory, "business model" is one of them.

The research of China Mobile's Internet of Things business model can summarize the development trend of
Internet of Things and the research results of business models systematically, providing material to recognize Internet of Things business mode. The paper also analyzes the weakness and imperfection of current business models and researches the Internet of Things business model suitable for China Mobile. China Mobile has had tries and applications in some fields, but still far away from scale use. It can help enterprises select the most suitable business models to grow through analyzing and contrasting the weakness and imperfection of current operating models, using the advantages of other business models for improvement. It also offers strategy advice for China Mobile conforming to the business model, to help China Mobile complete strategy transition of Internet of Things era.

\section{SUMMARY}

\section{A. Definition of Internet of Things}

Internet of Things refers to a kind of network taking use of information sensing equipments like radio frequency identification, infrared sensor, GPS (global position system) and laser scanner and so on, abiding the previously agreed protocol, connecting and combining things with internet, exchanging and communicating data and information at the same time, to realize things identification, positioning, monitoring management and other series of intelligent activities.

\section{B. Development situation of domestic and overseas Internet of Things}

Brief introduction of overseas development:

EPC Internet of Things grows up with the development of RFID. In November, 2005, ITU published an "Internet of Things" report in Tunis World Summit of Information Society. In the report, ITU made a prediction that the Internet of Things formed by active data exchange of "things" is just around the corner. Test work and progress has significant development. On June 22, 2004 EPCGfobal established and completed the first global standard of product electronic code technology, declaring the completion of the first generation of labeling standards, and subsequently tested in some applications. On June 28, 2004, EPCGfobal established a Public Policy Steering Committee, which is different from various trade associations, consumer goods companies, retailers, consisted of the representatives of standardization organizations. The Committee is committed to promoting the adoption of EPC technology guiding principles, responsible for providing training to the public and 
technology partners. EPC Internet of Things grows up with the development of RFID. EPC Internet of Things grows up with the development of RFID. In November, 2005, ITU published an "Internet of Things" report in Tunis World Summit of Information Society. In the report, ITU made a prediction that the Internet of Things formed by active data exchange of "things" is just around the corner.

Brief introduction of domestic development:

While developing abroad boomingly, EPC and Internet of Things has become an important area of attention in the big manufacturing country China, and is supported by relevant departments and enterprises. These departments include the Ministry of Science, Administration of Quality Supervision, National Standards Committee and so on. Many industries, research institutions, enterprises gradually carry out related research and application, to promote EPC related technologies. EPCGlobalChina formally established and held the "First China International EPC and Internet of Things High-level Forum" on April 22, 2004, to protect the whole EPC business, developing effectively from organization aspect. This event also marks the work of timely tracking the development of international EPC and Internet of Things technology, research and development of EPC technology related products, promoting EPC technology standardization, expanding EPC and practical applications is started officially.

\section{ANALYSIS ON THE BUSINESS MODEL OF CURRENT CHINA MOBILE INTERNET OF THINGS}

From the perspective of Internet of Things service providers, telecom operators have natural advantages to provide Internet of Things services, including existing, ubiquitous communications network coverage, anytime and anywhere access capability, skill experience in mobile internet field.

After years of technical research and product development in the field of M2M, China Mobile has formed a set of technical standards with independent intellectual property rights, solutions and related products currently, and has carried out diverse Internet of Things applications practice for different needs of customers for the government, industry and households.

Considering the shortage of China Mobile Internet of Things application, this chapter will not be limited in the space of China Mobile and current time, combining with the development trend of Internet of Things business model, to research from two aspects of Internet of Things business model applications field and typical features, and Internet of Things business model analysis, summarizing and analyzing the common characteristics of different market Internet of Things applications, contrasting and researching suitable business models of Internet of Things applications and thus to provide a reference for China Mobile's business model selection.

\section{A. Current China Mobile Internet of Things application model analysis}

Generally speaking, China Mobile has two kinds of application models regarding Internet of Things currently:

Firstly, in several relatively mature application areas, such as wireless meter reading in electricity industry, taxi positioning in transportation industry, the industries customers shall bear the whole or the most development expenses, and the operator only supply traditional channel.

Secondly, in several new developed industries, such as for the development and promotion of elevator defender project, the operation model is imperfect. The project cost is mainly born by the operators, and the related partners just coordinated for promotion. The actual benefit of operator was still from channel.

\section{B. The main issues of current China Mobile Internet of Things business model}

Under the joint efforts of all participants in the market, China Mobile Internet of Things business model experienced innovation and continuous growing, but our Internet of Things industry is still in the start period with fragmented applications, far away from large-scale industrialized promotion, there are still following problems existing:

- Standard system issues

Internet of Things business model is mainly crossindustry, cross-field applications. The characteristics of various industries and users are different, and there are no uniform standards and norms, resulting in its development, integration, deployment and maintenance cost higher, restricted scale application of Internet of Things business model.

- Industry integration issues, the objective of Internet of Things business model is to promote the integration of information technology and other industries deeply, which will touch on business process change, the transformation of mechanical equipments, personnel positions adjustment, so it is bound to encounter greater resistance .

- Improvement and innovation issues of Internet of Things business model, the industrial chain of the business model components are complicated, involving terminal manufacturers, application developers, network operators, end users, and many other links. The distribution of benefits of each link in difficult, hard to achieve win-win, which led to unsustainable business models and in need of innovation and diversity of Internet of Things business model.

- Privacy and security issues, with the continuous promotion of Internet of Things business models applications, it will involve more and more information concerning national security, corporate confidential information and personal privacy, which requires that the Internet of Things business model development not only needs technical protection, but also needs related authorities to develop appropriate laws and regulations to protect the user's information security and protect personal privacy.

- Under the conditions that voice business ARPU value continues to decline, the development of mobile Internet of Things business model is becoming a strategic focus of mobile operators. Mobile operators should learn the lessons of fixture Internet of Things business model, not to be content with only "pipeline", but to dominate the industry value chain, but mobile operator still has a lot of 
shortcomings in philosophy, organizational structure, and Internet of Things development capability.

\section{The Internet of Things business models that suitable for China Mobile}

For China Mobile, they must grasp the possible effects for the industry development of key technologies, conform to market development trend, select the best suitable business model, find new business growth point and realize continuous new increment of value to adapt the industrial development in Internet of Things era and keep leading position.

1) Based on uniform platform, promote development with integrated operation

"Based on uniform platform" means a platform is the base of developing Internet of Things business. In the big business model of platform operation, China Mobile develops and constructs Internet of Things operation and management platform, unifying Internet of Things codes and access standard.

"Promote development with integrated operation" means the detailed Internet of Things business operation on the platform can refer to the operation mode of industry applications, to conduct integrated operation for different businesses combining their characteristics.

2) Professional channel is fundamental, breakthrough from individual operation

In industry market, we suggest China Mobile to select the model of "professional channel is fundamental, breakthrough from individual operation", concentrating resources to supply the most professional and the most intelligent network channel. On the basis of channel supply, using industry characteristics, combing project BOT and integrator cooperation union and other models to improve industrial competitiveness, realize the breakthrough of plications promotion. "Professional channel is fundamental", "breakthrough from individual operation"

\section{DEVELOPMENT STRATEGY OF CHINA MOBILE INTERNET OF THINGS BUSINESS MODEL}

Based on "suitable business model for current China Mobile development" analysis, in line with the thinking of following business model to develop, the paper tried to provide some strategies and suggestions from research respects for China Mobile developing Internet of Things.

\section{A. Focus on key industry customers and key applications}

Large-scale development of Internet of Things business model in China is still in infancy. As an operator in the industry chain, China Mobile must take "point to area" strategy in order to promote the development of the whole industry. The preferred is focusing on key industry and key applications, through the point radiation effects, gradually covering the other sectors.

\section{B. Establish and launch an own brand facing Internet of Things business model}

In the process of building brands like Monternet, GSM, M-Zone, China has accumulated abundant brand operation experience successfully. In line with brand strategy advantage, China Mobile needs to establish and launch an own brand facing Internet of Things.

\section{Accelerate intelligent high-quality network construction}

High-quality network is the foundation. China Mobile needs to make long-term planning for the development of Internet of Things, and makes contribute to the investment and construction of network equipment, network platform, support systems, providing a good network environment for the rapid development of Internet of Things business. Intelligence support is the guarantee. The key of network intelligence is to play its control on billing, service, and value-added services to meet the individual needs of Internet of Things applications.

\section{D..Build the access and management platform of Internet of Things business model}

Platform has a pivotal role in the Internet of Things industry chain. To develop Internet of Things business model, we must build Internet of Things access and management, not only to achieve unified network access, but also to meet the national management support. Platform is as important as network, the radio and TV system HFC speed seems not slower than ADSL, but the development of it is clearly much weaker. The root of the problem lies neither in network bandwidth, nor the content of radio, it is because the ratio and TV industry is lack of system platform integrating management, billing and support in one.

\section{E..Build Internet of Things business model mobile cooperation union}

China Mobile must have a clear understanding that in the era of rapid development of Internet of Things, it is no longer possible for dominant situation, only cooperation can win. Thinking needs to change as soon as possible, and change the traditional mode of operation, giving up absolute control of the industrial chain appropriately, taking business application as a starting point, extensively developing industry chain cooperation, to find a reasonable win-win cooperation model together.

\section{F..Strategic development of Internet of Things business model marketing and promotion}

Network and platform is the foundation and cooperation union is the guarantee. On the basis, the Internet of Things business model marketing and promotion needs to be developed strategically, too.

1) Strengthen maintaining the relationship of potential customers and enclosure reserve

It is necessary to implement customers "closure" strategy for China mobile, aiming at the focused key breakthrough industries or other huge potential industries. In the period of market cultivating, China Mobile should strengthen maintaining the relationship with big customers, to establish customer base for Internet of Things applications scale promotion.

2) Strengthen Internet of Things business model applications and promote teams construction

Compared with other application of informatization, Internet of Things business model application promotion will have more difficulty and longer cycle. The traditional promotion model of "business opportunities and transmission taking customer managers as the main body", "realize business opportunities transmission taking 
industry manager and support manager as the main body" is difficult to meet the promoting requirements of newly developing Internet of Things business model applications.

Internet of Things business model advance team should be equipped with a full-time industry manager (or project manager) implementing opportunities exploration, a fulltime support manager to achieve business opportunity transformation. Meanwhile, Internet of Things industry managers (or project managers) also need to strengthen the comprehensive technical, ability training, to make their communication skills, demands extracting ability, and project control ability fully meet customers' and market demand.

\section{CONCLUSION}

With the growing maturity of technology and standards related to Internet of Things, man-machine communication and machine to machine communication based on $\mathrm{M} 2 \mathrm{M}$ is the secondary important blue ocean after human communication. The business characteristics of Internet of Things applications determine that the traditional MONTERNET mode is no longer viable. To continue to stay ahead in the Internet of Things era, China Mobile must follow the market rules, choose their own business model, and precede strategic reserves from intelligent network construction and other perspectives.

To complete the strategic transformation in Internet of Things era and occupy an important position in the market, the paper suggests that China Mobile should work from the following aspects: firstly, it is necessary to speed up the construction of high-quality intelligent network, secondly, it is fundamental to establish network access and management platform, thirdly, it is important to jointly build a mobile alliance of Internet of Things, fourthly it is vital to launch the marketing activities on Internet of Things. The paper summarizes the development trend of
Internet of Things and the research results of business models systematically, providing material to recognize Internet of Things business mode. The development of Internet of Things is in the ascendant, and it will bring great impact to the enterprise's business scope, mode of operation, while the man-machine communication based on Internet of Things is also important blue ocean market for China Mobile in the future. To recognize, research the impact brought by Internet of Things has far-reaching significance for enterprises.

\section{REFERENCES}

[1] Steve Melon, Toward a Global" Internet of Things", SUN,November 11,2003

[2] The performance of communication industry main indexes of Nov. 2008, People's Republic of China Ministry of Industry and Information (http://miit.gov.en/nl1293472/nl1295057/n 1298505/118485.html), Dec. 25th, 2005

[3] Statics report of the 23rd Chinese internet development situation, China Internet Network Information Center (CNNIC), 2009

[4] Sun Haoming, Song Juan, Mobile internet development strategy discussion, Communication technology policy research, June, 2008, the third publication: 2008

[5] Survey report on IWA development situation, China Internet Network Information Center (CNNIC), May, 2007

[6] Beijing University of Posts and Telecommunications Information Management and Information Economics Laboratory Telecommunications and Regulations Research Center, Operator internet business operation research, August, 2007

[7] Master degree thesis of Beijing University of Posts and Telecommunications, Operator orientation mobile internet business model design, 2009;

[8] Ma Chunshan, Operation model of $3 \mathrm{G}$ value added service and discussion of profit model, Mobile communication, March, 2008 (first half)

[9] Zhou Shiquan, Analysis of the mobile operator core abilities in $3 \mathrm{G}$ era, China National Knowledge Infrastructure 